Volume 1, No. 3, September - December 2016 ISSN: 2503-4235 (p); 2503-4243 (e)

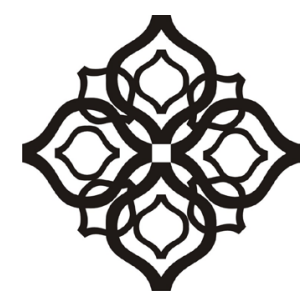

Shirkah

Journal of Economics and Business 


\section{Shirkah}

\section{Journal of Economics and Business \\ Vol. 1, No. 3, September-December 2016 \\ ISSN: 2503-4235 (p); 2503-4243 (e)}

\section{Editor in Chief}

Sri Walyoto

\section{Editorial Boards}

Abu Umar Faruq Ahmad, UBD School of Business and Economics, Brunei Darussalam

Amelia Fauzia, Asia Research Institute, National University of Singapore, Singapore

Cedomir Nestorovic, ESSEC Business School Asia Pacific, Singapore

Dwi Condro Triono, Faculty of Islamic Economics and Business, IAIN Surakarta, Indonesia

Fahmy Radhi, Faculty of Economics and Business Universitas Gadjah Mada, Yogyakarta, Indonesia

Hasan Basri, Syiah Kuala University, Aceh, Indonesia

Jaka Sriyana, Faculty of Economics, Universitas Islam Indonesia, Yogyakarta, Indonesia

Johan Fischer, Department of Social Sciences and Business Roskilde University, Denmark

Masudul Alam Choudhury, Postgraduate Program in Islamic Economics and Finance, Trisakti University, Jakarta, Indonesia and the College of Economics and Political Science (CEPS) in Sultan Qaboos University (SQU), Oman

M. Falik Isbah, School of Humanities and Social Science, University of New South Wales, Australia

M. Ishaq Bhatti, La Trobe Business School Department of Economics and Finance La Trobe University, Australia

Nunung Nurul Hidayah, Aston Business School, Aston University, Birmingham, United Kingdom

Najib Kailani, Pascasarjana, Universitas Islam Negeri (UIN) Sunan Kalijaga, Yogyakarta, Indonesia

Shaikh M Ghazanfar, Departement of Economics, University of Idaho, Russian Federation 
Managing Editors

M. Endy Saputro

M. Zainal Anwar

\section{Assistant to Editor}

Supriyanto

Shirkah Journal of Economics and Business is a peer-reviewed journal published three times a year (January-April, May-August and September-December) by Faculty of Islamic Economics and Business, Institut Agama Islam Negeri (IAIN/ State Institute for Islamic Studies) Surakarta Central Java, Indonesia. The main objective of Shirkah is to offer an academic space of exchange ideas and initiate the increase number of qualified article produced by postgraduate students, practitioners and academicians.

\section{Editorial Office}

Ruang Jurnal Shirkah

Lantai Dasar, Sayap Barat, Fakultas Ekonomi dan Bisnis Islam, IAIN Surakarta

Jln. Pandawa No. 1, Kartasura, Sukoharjo, Jawa Tengah Kode Pos. 57168

Phone (+62271) 781516 Fax: (+62271)782336

E-mail: shirkahiainsurakarta@gmail.com

Website: http://shirkah.or.id/ 



\section{Shirkah}

\section{Journal of Economics and Business}

Vol. 1, No. 3, September-December 2016

ISSN: 2503-4235 (p); 2503-4243 (e)

\section{Table of Contents}

\section{Articles}

Muhfiatun

The Effect of Sharia Monetary Policy and Financing Quality on Financial Performance in Sharia Banking

Roro Hindun

Izzul Fatchu Reza

Understanding Indonesian People Borrowing Money

from Banks and Non-Banking Institutions

M. Nur Rianto Al Arif

299

Monopoly and Ikhtikar in Islamic Economics

Trimulato

Sharia Bank Product Development through Mudhrabah Investment

Aida Nurul Hadiah

Financial Services Authority (OJK) Policy on Debt Proportion and Its Impact on the Profitability of DES Listed Companies in Indonesia

Statement of Financial Accounting Standard (PSAK)

No. 109 and Its Implementation in Several Zakat Management

Organizations in Malang, East Java 



\title{
Statement of Financial Accounting Standard (PSAK) No. 109 and Its Implementation in Several Zakat Management Organizations in Malang, East Java
}

\author{
Henny Triyana Hasibuan \\ Universitas Udayana, Bali
}

\begin{abstract}
Indonesian Accountant Association (IAI) has issued the statement of financial accounting standards No. 109 (PSAK No. 109) regarding zakat, infaq, sadaqah (ZIS). This research was conducted on several Zakat Management Organization (OPZ) in Malang, East Java. The research aims to analyze the consistency of the PSAK application in some OPZ in Malang in accordance with Statement of Financial Accounting Standards (PSAK) No. 109. As a result, this research finds that some OPZ in Malang do not prepare financial statements in accordance with PSAK 109. The financial statements of the OPZ is reported only in the form of income statements and distribution funds, while excludingsuch statements asfinancial position, changes in funds, changes in assets, cash flow and remarks to the financial statements. This research give a salient contribution of analyzing the implementation of zakat, infaq and sadaqah in Indonesia.
\end{abstract}

Keywords: PSAK No.109, Indonesian Accountant Association (IAI), zakat, infaq, sadhaqah

Indonesia, culturally and demographically has proper potential to develop the management of zakat, infaq, and shadaqah (ZIS). It is due to Indonesian demographics' Indonesian majority people are muslim, and culturally the duty of zakat, infaq, and shadaqah in Allah way has strongly rooted in Muslim people life tradition. According to standard statement of financial accounting PSAK no. 109, zakat is the treasure supposed to be paid by muzakki as mention in sharia law to the people who have the 
rights to accept it (mustahiq). The language considered zakat meaning as grow (numuw) and increase (ziyadah), whether it pronounces zakat al$z a r$, means the plant is growing and increasing. Whether it is pronounces zakat al-nafaqah means the income will grow and increase due to blessing. This word is often mentions in the meaning of thaharah (pure). Allah says, "Truly he succeeds that purifies it" (QS. Al-Shams:9).

Zakat according to term or shara' means the required portion (excluded from) treasure. Maliki School define it as "excluding special portion from special treasure which has achieved nishab (limit quantity for $z a k a t$ ) to the people entitled to accept it (mustahiq). The requirement is full ownership and has achieved haul (one year), not minerals, and not plantation." The position of zakat obligation in Islam is highly fundamental and basic. Alqur'an often mentions the words zakat and shalat at the same time, meaning there is complementation relation between shalat and zakat. Shalat has deity-vertical dimension, whereas zakat in the Alqur'an often accompanies with significant threat. Zakat as the third pillar of Islam is the main instrument in Islamic teaching with the function as wealth distributor from the have to the have not. It is a legal institution to create equalization and justice for the people therefore the people life level could be enhanced (Ayuniyyah, 2011).

The Zakat implementation will be effective under the zakat management organization. The Law No. 381999 chapter III mentioned zakat management organization consists of two organization types, namely Badan Amil Zakat (article 6) established by government and Lembaga Amil Zakat (article 7) established by society. It means zakat is the worship with horizontal-humanity dimension. Allah says, “... and there are those who bury gold and silver and spend it not in the Way of God: announce unto them a most grievous penalty. On the day when heat will be produced out of that (wealth) in the fire of Hell, and with it will be branded their 
foreheads, their flanks, and their backs. - "This is the (treasure) which ye buried for yourselves, taste ye then the (treasure) ye buried!" (QS. AlTaubah: 34-35).

OPZ (Organisasi Pengelola Zakatl Zakat Management Organization) should use the correct administration and readily audited by public accountant whereas the zakat has not yet applied zakat accounting. The problem will emerge on financial report audit of the amil zakat institution. The audit is important to enhance society trust on zakat management organization (Ikatan Akuntan Indonesia, 2011). The expense budget management is simple. The administrator has set the accounting system as the soul and expectation of Sura Al-Baqarah verse 282, providing periodical and transparent report, observing with audit examination by independent party such as public accountant. Therefore the budget expense is accountable to Allah and Muslim people which highly maintained in Islam. The closing of Sura Al-Taubah mentions, “... God sufficed me, there is no God but He, on Him is my Trust," and Sura Al Baqarah verse 282: "Ye, who believe! When we deal with each other in transaction involving future obligations in a fixed period of time, reduce them to writing. Let a scribe write down faithfully as between the parties, let not the scribe refuse to write as God has taught him ...." The verse states whereas zakat should have accountability and transparency. It means all of the processes mentions above should be carried out in responsible manner. Allah will hear all complains of the mustahiq who have the right on the portion but not receiving it. Allah will also hear complains of the muzaki who commend their treasure to be given to the mustahiq but not yet given. It is important for the OPZ to create transparent and good financial report. There are many BAZIS, OPZ, and LAZIS which have not yet applied zakat accounting, especially the ones operating at the scope of village/ sub-district or mosque. They are still using conventional accounting even though there is zakat accounting (Hafidhuddin, 2011; cf. Hamat, 2014). 
This research is based on the phenomenon of zakat accounting application on zakat management organization. The zakat obligation's optimal application is impossible without good management including administration (accounting function) to guarantee the justice principle implementation on involving parties namely amil zakat organization and amil zakat institution (Karim and Azhar, 2009; Mansyur, 2011). This research purpose is observing the financial report application on OPZ at Malang whereas it has applied as mentions on the Financial Accounting Standard Statement (Pernyataan Standar Akuntansi Keuangan/ PSAK) No. 109.

\section{Zakat Accounting}

Zakat is one of the pillars of Islam and one of the basic obligation in Islam. Zakat main reason is developing balance social economic development and to purify a person's soul and wealth to be blessed by Allah. Zakat has several characteristics mentions at the PSAK No. 109 (IAI, 2011) explaining various zakat characteristics. First, Zakat is sharia obligation should be given by muzakki to the mustahiq through the amil or directly. The zakat provisions are about nishab requirements, haul (periodical or non-periodical), zakat tariff (qadar), and its allocation. Second, Infakl shadaqah are voluntary donation, determined or not-determined and its allocation is determined by the infak/ shadaqah provider. Third, Zakat and infak/ shadaqah accepted by the amil should be managed according to the sharia principles and good management.

Accounting definition is the process of recording, categorizing, summarizing, reporting, and analyzing an organization financial data. Accounting means providing information on the economics condition of company or organization at certain period as management accountability, the business result at certain period, and also as management accountability 
to make decision in business language. Based on accounting definition above zakat mal accounting is considered as one of accounting subjects specializing in determining and deciding zakat obligation asset, measuring the volume, and distributing its result to the mustahiq base on Islamic sharia principles. The definition shows the main purpose of accounting: accountability, applying management function (planning, organizing, actuating and controlling), observation, and tool in decision making. The other purposes of zakat accounting according to AAS-IFI (Accounting \& Auditing Standard for Islamic Financial Institution) is providing information on organization obedience on Islamic sharia provision, including information on incomes and expenses forbidding by sharia whereas it happens and its distribution. The purpose shows the significance of sharia committee (issuing sharia opinion) (Ikhsan, 2003; Rahman 2011).

Accounting, in fact, is one of Islamic teaching, meaning it is liberally given to human's thought to develop it, due to its nature as muamalah business. There are Islamic values in accounting and there is accounting in Islamic muamalah and law. Both are inclined to truth with different accountability significance, dimension, and quality level. However, due to the matter significance Allah providing a space in the Alqur'an on this matter at Sura Al-Baqara verse 282, "Ye, who believe! When we deal with each other in transaction involving future obligations in a fixed period of time, reduce them to writing. Let a scribe write down faithfully as between the parties, let not the scribe refuse to write as God has taught him ...." The verse shows there is recording culture in Islam civilization. There is holy command since the Prophet Muhammad era on recording system inclines for the purposes of truth, assurance, openness, and justice between two parties involving in muamalah relation (Sarif and Kamri, 2009; Suroso, 2007). 
Therefore, accounting is significance in each transaction of the company or trades due to recording for justice and truth. Many people consider the significant function of Islamic accounting is zakat accounting to count zakat. Kanji and Abd. Hamid Habbe (2011), however considers Islamic accounting is not only counting and reporting zakat and larger than the definition. It is due to Islamic accounting as part of people social system therefore should be able creating Islamic lifestyle as mentioned in Islamic norms and sharia. The Islamic sharia experts and accountants should find the basic to apply and develop different accounting standard than presently known banking accounting standard and conventional financial institution. The standard accounting is the success key for zakat management organization providing the people. The institution is generally providing information which is proper, trustable, and relevant with consideration of Islamic sharia context.

Standard zakat accounting, in fact has different rules and due to the zakat's nature the standard will follow the treasure evaluation. Zakat accounting standard in general could be defined as: comparison with present market price, one year rule, treasure/ asset, activa without zakat portion, nishab (limit/ total). Zakat transaction is the transaction of zakat, infaq, and shadaqah. The zakat organization management accountability shows on the financial report legalized by legal organization using correct bookkeeping system, and readily to be audited by public accountant. It means zakat accounting standard is highly needed. Due to PSAK No. 109, zakat accounting purpose is managing bookkeeping, evaluation, representation, and explanation on zakat, infaq/shadaqah (Istutik, 2011). 


\section{Component of PSAK No. 109}

The PSAK No. 109 consists of zakat, infaq/ shadaqah with several financial report components which should made by the amil completely. The report should include: balance (financial position report); budget changes report; management changes report; cash flow report; and financial Report Notation. The accounting action base on PSAK 109 shows on Table 1 below

Table 1: The Accounting Action Base on PSAK No. 109

\begin{tabular}{|l|l|c|}
\hline No & \multicolumn{1}{|c|}{ Elements } & \multicolumn{1}{c|}{ PSAK No. 109 } \\
\hline 1 & Acknowledgement & $\begin{array}{l}\text { 1. Zakat acceptance was acknowledged at } \\
\text { cash and non-cash acceptance } \\
\text { 2. Accepted Infaq/ shadaqah are } \\
\text { acknowledged as budget addition. } \\
\text { Related ot not related in accordance } \\
\text { with the provider purpose with the right } \\
\text { amount and non-cash proper value. } \\
\text { 3. Zakat distribution to Mustahiq is } \\
\text { acknowledged as } z a k a t \text { budget reduction } \\
\text { with the amount of: } \\
\text { a. The budget is in cash } \\
\text { b. The recorded budget is in non-cash } \\
4 . \text { Infaq/shadaqah distribution to Mustahiq } \\
\text { is acknowledged as zakat budget } \\
\text { reduction with the amount of: } \\
\text { a. The budget is in cash } \\
\text { b. The recorded budget is in non-cash } \\
\text { asset }\end{array}$ \\
\hline
\end{tabular}




\begin{tabular}{|c|c|c|}
\hline & & $\begin{array}{l}\text { 5. The zakat, infaq, and shadaqah reduction } \\
\text { asset values are acknowledged as: } \\
\text { a. Zakat budget reduction is not due to } \\
\text { amil carelessness; } \\
\text { b. Amil budget reduction and loss is due } \\
\text { to amil carelessness. }\end{array}$ \\
\hline 2 & Evaluation & $\begin{array}{l}\text { Accepted proper non-cash asset assessment } \\
\text { is using market price. Whereas it is } \\
\text { unavailable a certain value provision } \\
\text { method will be used base on relevant SAK. }\end{array}$ \\
\hline 3 & Report & $\begin{array}{l}\text { Complete amil financial report component } \\
\text { consists of: } \\
\text { a. Financial position report, } \\
\text { b. Budget changes report, } \\
\text { c. Management asset changes report, } \\
\text { d. Cash flow report, } \\
\text { e. Financial report's notation. }\end{array}$ \\
\hline 4 & Presentation & $\begin{array}{l}\text { Amil provides ZIS budget and amil budget } \\
\text { and present them separately at financial } \\
\text { position report. }\end{array}$ \\
\hline 5 & Explanation & $\begin{array}{l}\text { 1. Explanation in details the amount of ZIS } \\
\text { budget distribution for each Mustahiq. } \\
\text { 2. ZIS and amil budget distribution } \\
\text { policy for amil and non-amil, such as } \\
\text { distribution percentage, reason, and } \\
\text { policy consistency. } \\
\text { 3. Proper value determination method in } \\
\text { accepting ZIS non-cash asset; }\end{array}$ \\
\hline
\end{tabular}




\begin{tabular}{|l|l|}
\hline 4. Infaq/ shadaqah distribution policies, \\
such as priority scale determination \\
on Infaq/ shadaqah distribution and \\
acceptance; \\
5. Infaq/ shadaqah budget management \\
before distribution should be explained \\
clearly its amount and percentage \\
from all Infaq/ shadaqah acceptance at \\
reporting period and its reasons;
\end{tabular}

There are several matters to be evaluated on Zakat and Infaq/ shadaqah ED PSAK (Nikmatuniayah, 2011), namely: First, Ed (Exposure Draft) PSAKZIS is in accordance with law No.38 1999 on zakat, infaq, and shadaqah (OPZIS) made the management more clear and focus. Second, the amil budget collection and distribution is not completely managed. ED PSAK only explains the outline amil budget source namely from the zakat, infaq, and shadaqah budget. The portion is taken in accordance with amil obligation and sharia provision. The part need to be revised is addition role of Dewan Pengawas Syariah (DPS/ Sharia Trustee Committee) as one of its characters. DPS consideration in deciding the amil portion taken from the zakat, infaq, and shadaqah budget is highly significant to assure the amil will not unilaterally determining their portion from zakat, infaq, and shadaqah budget.

Third, ED PSAK has not yet accommodating other budgets managed by the OPZIS (Organisasi Pengelola ZIS/ ZIS Management Organization) which has been done by Yayasan Dompet Sosial Al-Fala (YSDF) namely kind of humanity budget, education budget, or other kind of budgets programmed by each institution. According to shariah those budget could be categorized as zakat or infaq budget with consideration 
on practice accommodation therefore the accounting acknowledgement and evaluation is clearer. Fourth, The ED SPAK has not yet accommodate the possibilities of budget inter-transfer, for example certain amount zakat budget was transferred to infaq/shadaqah budget due to emergency situation or at short term and will be returned in short term. The ED SPAK should create regulation to allow or not this practice therefore the status of this emergency act is clear for several OPZ practice it. Fifth, financial report components should be separated from other budget for example zakat budget balance, infaq/ shadaqah budget balance, infaq/ shadaqah budget report changes, and others even though in the end all financial reports are merged.

\section{Using Qualitative}

This qualitative descriptive research will explain factual form condition and financial report component of belongs to amil institution. It will describe and define the applied ZIS accounting standard (PSAK No. 109). The research was carried out on five OPZs at Malang namely YDPS Abu Dzar Al-Ghifari, YBM Al-Umm Mosque, Baitul Maal Hidayatullah (BMH), Yayasan Dana Sosial Al-Falah (YDSF), LAZ Nurul Hayat, and YBM (Yayasan Bina Mujtama).

The data was collected with documentation method from each amil institution OPZ websites to study its policies; working programs; budget collecting system, procedure and distribution; and also the financial accountability. The data was also gained from interviews to the administrators and questionnaires distributed to the amil institution administrators. The data will show ZIS standard accounting understanding. The research was carried out in September 2016. The opinion options consisted of five categories with 4 scores for of strongly agree answer, 3 for agree answer, 2 for neutral answer, 1 for disagree answer, and 0 for 
strongly disagree answer. There were 30 returning questionnaires from amil institution administrator.

Total Range Evaluation:

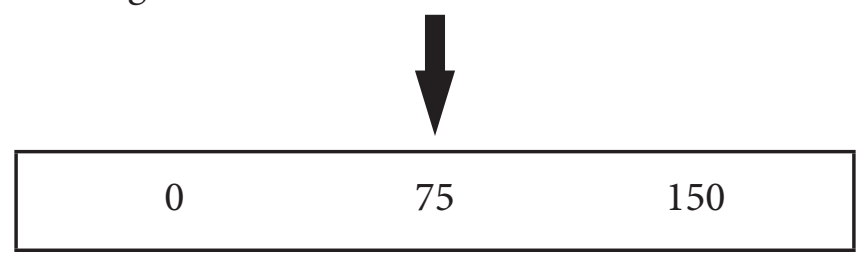

\section{Picture 1: ZIS Standard Accounting's Range Understanding}

The qualitative analysis to measure whereas the published financial report forms and component has implemented ZIS standard accounting (PSAK No. 109). The evaluation was carried out with OPZ understanding on PSAK No. 109.

\section{Implementing the PSAK}

The research was carried out on five OPZ at Malang namely YDPS Abu Dzar Al-Ghifari, YBM Al-Umm Mosque, Baitul Maal Hidayatullah (BMH), Yayasan Dana Sosial Al-Falah (YDSF), LAZ Nurul Hayat, and YBM (Yayasan Bina Mujtama). All five studied amil zakat institution has legality from Religious Affair Ministry, Law and Human Rights Ministry, and completed with Notaries Instrument in accordance with administrator understanding on amil institution.

Table 2: Understanding Score on Financial Report Legality

\begin{tabular}{|l|c|}
\hline \multicolumn{1}{|c|}{ Statement's Understanding } & Score \\
\hline OPZ is zakat, infaq and shadaqah institution which & 125 \\
establishment or inauguration management is base on the \\
law. The institution purposes are collecting and distributing \\
zakat, infaq and shadaqah.
\end{tabular}


The five OPZ was studied until the end of 2015. They have ZIS budget financial accountability on the budget collection and distribution. However, the financial report forms and components of these five amil institution was not determining ZIS standard accounting (PSAK No. 109). The written financial report will provide information on incoming and expenses cash flow, and not cash flow report regulated in PSAK. The report period for the amil institution income and expense cash report studied from monthly to annually period. The cash income was categorized according to zakat, infaq and shadaqah incoming source, and expense cash is categorized according to the activities or acceptor groups (for example education, orphan, dhuafa). The institution financial report form was not determining the understanding on PSAK No. 109.

Table 3: Understanding Score on Standard Accounting Implementation (PSAK No.109)

\begin{tabular}{|l|c|}
\hline \multicolumn{1}{|c|}{ Statement's Understanding } & Score \\
\hline $\begin{array}{l}\text { OPZ need to create financial accountability on the zakat, } \\
\text { infaq and shadaqah management activities in society. }\end{array}$ & 113 \\
\hline $\begin{array}{l}\text { OPZ accountability should be written in financial report in } \\
\text { accordance with ZIS standard accounting (PSAK No.109) }\end{array}$ & 95 \\
\hline OPZ financial report should be carried out periodically & 91 \\
\hline
\end{tabular}

Amil institution administrators' majority education level is $95 \%$ bachelor graduates. The administrators in general agree on the PSAK No. 109 shari'ah standard accounting application. Therefore their knowledge was limited on the existence of shariah standard accounting which regulating ZIS accounting. The understanding on PSAK No. 109 contents is limited; therefore the administrator understanding on amil institution financial report is also limited. 
Table 4: Understanding Score on Financial Report Components

\begin{tabular}{|l|c|}
\hline \multicolumn{1}{|c|}{ Statement's Understanding } & Score \\
\hline OPZ understands the ZIS standard accounting (PSAK 109) & 51 \\
\hline $\begin{array}{l}\text { OPZ financial report writing refers to ZIS standard accounting } \\
\text { (PSAK 109) }\end{array}$ & 78 \\
\hline $\begin{array}{l}\text { OPZ financial report consists of: balance (financial position } \\
\text { report, budget changes report, managing asset changes report, } \\
\text { and financial report notation) }\end{array}$ & 43 \\
\hline
\end{tabular}

The administrator understands whereas zakat budget belongs to the amil will be used to manage amil institution. However, they lack of understanding on the separation of amil budget representation from zakat budget and infaq/shadaqah budget. The "Budget Changes Report" and "Managing Asset Changes Report" were not available in financial accountability report written by the studied amil institutions. The amil institution administrator understanding on those two reports is limited.

Table 5: Understanding Score on Source Changes

\begin{tabular}{|l|c|}
\hline \multicolumn{1}{|c|}{ Statement's Understanding } & Score \\
\hline $\begin{array}{l}\text { Amil budget is the Amil institution right on the budget of } \\
\text { zakat, infaq and shadaqah and other budgets from the provider } \\
\text { for amil and used for amil institution management. }\end{array}$ & 68 \\
\hline $\begin{array}{l}\text { OPZ understands zakat budget and infaq/ shadaqah budget } \\
\text { should be separated from amil budget. }\end{array}$ & 39 \\
\hline $\begin{array}{l}\text { OPZ understands whereas 'Budget Changes Report' consists } \\
\text { of } z \text { akat budge, infaq/ shadaqah budget, amil budget and } \\
\text { non-halal budget. }\end{array}$ & 39 \\
\hline $\begin{array}{l}\text { OPZ understands whereas 'Managing Asset Changes Report' } \\
\text { consists of managing asset changes from the infaq/ shadaqah } \\
\text { budget source. }\end{array}$ & 36 \\
\hline
\end{tabular}


The amil institution collects budget from the people especially muzakki, therefore it should publishes or delivers to society, financial report. For example is OPZ Al-Falah (YDSF) Malang publishes its financial report on its magazine and on its website. The financial report publication could be carried out with announcement or mass media whereas it is possible. The purpose is providing opportunity for the society to evaluate the amil institution (cf Suroso, 2007; Wibisono, 2011; Yakub, 2011).

\section{Conclusion}

The financial accountability on zakat, infaq and shadaqah budget income and distribution has been carried out by amilinstitution in Malang. However these institutions have not yet applied ZIS standard accounting (PSAk No. 109) in writing its financial report. The financial report is limited on cash income and expense cash. Amil institution administrator recognition moreover understanding is highly deficient. The involvement of universities, profession organization, or BAZNAS is highly needed on PSAK 109 training. The majority bachelor graduate education level of the amil institution's administrator will enhance their understanding on PSAK 109 rapidly. The amil institution financial reports need to be published to the society using their alternative media, such as announcement board at the amil institution secretariat office, magazine, website, or other media. 


\section{References}

Ayuniyyah, Q. (2011). Factors Affecting Zakat Payment Through Institution of Amil Muzaki's Perspectives Analysis (Case Study of Badan Amil Zakat Nasional BAZNAS), Jurnal Ekonomi Islam AlInfaq,Vol.2, No.2, September, pp.1-16.

Badan Amil Zakat Nasional, Laporan Keuangan Tahun 2011 Audited, http://www.baznas.or.id/laporan, retrieved August 10, 2016

Hafidhuddin, D. (2011). PSAK Zakat Harus Dipaksakan, Majalah Akuntan Indonesia, No.3, September-Oktober 2011.

Hamat, Z. (2014). Sustainable Zakat Accounting in Malaysia: an Analysis, Mediteranian Journal of Social Sciences, Vol 5 (19), pp. 139-146.

Ikhsan, A., and Agus, E.S. (2003). Membangun Standar Akuntansi Islam \& Perspektif Zakat, Jurnal Akuntansi \& Keuangan, Vol 2, No.2, September, pp.188-199.

Ikatan Akuntan Indonesia. (2011). Pernyataan StandarAkuntansi Keuangan (PSAK) No. 109 tentangAkuntansi Zakat dan Infak/Sedekah.

Ikatan Akuntan Indonesia. (2011), Pernyataan Standar Akuntansi Keuangan (PSAK) No. 101 Revisi 2011 tentang Penyusunan dan Penyajian Laporan Keuangan Syariah.

Istutik. (2011). Bagaimana Bentuk Laporan Keuangan Amil?, http:// blog.stie-mce.ac.id/istutik/2011/05//bagaimana-bentuk-laporankeuangan-amil/ retrieved November 10, 2016.

Kanji, L., and Abd. Hamid Habbe, Mediaty. (2011), Faktor Determinan Motivasi Membayar Zakat retrieved http://pasca.unhas.ac.id/jurnal/ files/ November, 162015.

Karim, A.A., \& A. Azhar, S. (2009). Fenomena Unik di Balik Menjamurnya Lembaga Amil Zakat (LAZ) di Indonesia, Zakat \& Empowering. Jurnal Pemikiran dan Gagasan Vol I, 2009. 
Kementerian Hukum dan HAM RI, (2011). Undang-Undang No.23 Tahun 2011 tentang Pengelolaan Zakat, Jakarta.

Mansyur, A.F. (2011). Gundah Gulana dalam Aset Kelolaan. Majalah Akuntan Indonesia, No.3, September-Oktober.

Nikmatuniayah. (2011). Perlunya Pelaporan Zakat untuk Publik, Teknis, Vol.5, No.2 Agustus, pp.91-96.

Rahman, I.A. (2011), ZakatuntukMemberdayakan Kaum Dhu'afa, retrieved from http://www.elzawauinmaliki.org/zakatuntuk-memberdayakankaum-dhuafa/ November 152015.

Sarif, S.S., \& Nor 'Azzah Kamri. (2009). A Theoretical Discussion of Zakat for Income Generation and Its Fiqh Issues, Shariah Journal, Vol. 17, No. 3, pp. 457-500.

Suroso. (2007). Manajemen Badan Amil Zakat Infaq dan Shadaqah dalam Upaya Pemberdayaan Ekonomi Islam, Fordema,Vol 7, No.1, Juni, pp.99-114.

The Holy Qur'an Text and Translation (transl. Abdullah Yusuf Ali). (2007). Kuala Lumpur: Islamic Book Trust.

Wibisono, J. (2011). Rekor Manis PSAK Zakat, Majalah Akuntan Indonesia, No.3, September Oktober.

Yakub. (2011). Penyaluran Zakat dari Perspektif Akuntansi, Majalah Akuntan Indonesia, No.3, September-Oktober. 
Vol. 1 No. 3, September - December 2016 